\title{
Steering Business in Kenya Through Difficult Economic Environment
}

\author{
Dr. Richard Isaac Mwangangi \\ School of Business, The East African University
}

\begin{abstract}
This paper presents strategies on how to steer business through difficult economic period. It defines leadership and explains the key concepts in corporate governance; effectiveness and efficiency, resources management, quality delivery and adding value in corporate governance. The paper also focuses on the corporate governance aspect of strategic management; role of the board of directors in crafting and executing strategy. The different levels of management are also discussed in this paper; strategic, tactical and operational. All these concepts are examined with a view to highlight their importance in the effective and efficient management of business organizations. In an operating environment that is dynamic and highly competitive, business organizations need to appreciate the importance of crafting and effectively executing strategies that can help them create sustainable environment to carry it through any unexpected and challenging eventuality. The paper concludes that effective and efficient management of resources, quality delivery and adding of value could drive the organisation through economic crisis like COVID-19 epidemic successfully.
\end{abstract}

Keywords: Corporate Governance, Effectiveness and Efficiency, Resources Management, Quality Delivery, Adding Value.

DOI: $10.7176 / \mathrm{EJBM} / 13-24-08$

Publication date: December $31^{\text {st }} 2021$

\section{Introduction}

Leadership is a process of social influence in which one person can enlist the aid and support of others in the accomplishment of a common task (Covey, 2011). It is organizing a group of people to achieve a common goal. According to Anderson, Swaminathan \& Mehta (2018), in tough economic times, most companies turn almost automatically to cost cutting strategies as they try to survive. It takes exceptional management mettle and long term clear sightedness to avoid this common managerial reaction which can lead to counterproductive and sometimes disastrous results for the company's future. Often overlooked in the desire to do something fast to stabilize the company is that cost reductions are also likely to reduce product innovation and customer service which leads to dissatisfied and eventually lost customers.

According to Mensah (2012), governance is referred to mean all processes of governing, whether undertaken by a government, market or network, whether over a family, tribe, formal or informal organization or territory and whether through laws, norms, power or language. He further stated that it relates to the processes of interaction and decision-making among the actors involved in a collective problem that lead to the creation, reinforcement, or reproduction of social norms and institutions. Corporate governance is the process by which organisations are directed, controlled and held to account (Lashgari (2014).

\section{Effectiveness And Efficiency}

Effective is the adequacy to accomplish a purpose; producing the intended or expected results. Efficient is performing or functioning in the best possible manner with the least waste of time and effort. In other words, being effective is about doing right things while being efficient is about doing things right.

In a difficult economic climate, service organisations often face a thorny dilemma; budgets continue to shrink, yet they are expected to produce positive results. Essentially, they have to work on their efficiency on their effectiveness to survive. However, this is often easier said than done. This has led many establishments to downsize their labour resources as well as reduce operating expenses (Weber, 2002). Paradoxically, companies operate on blame game attitude and make very irrational decisions in an effort to survive. 


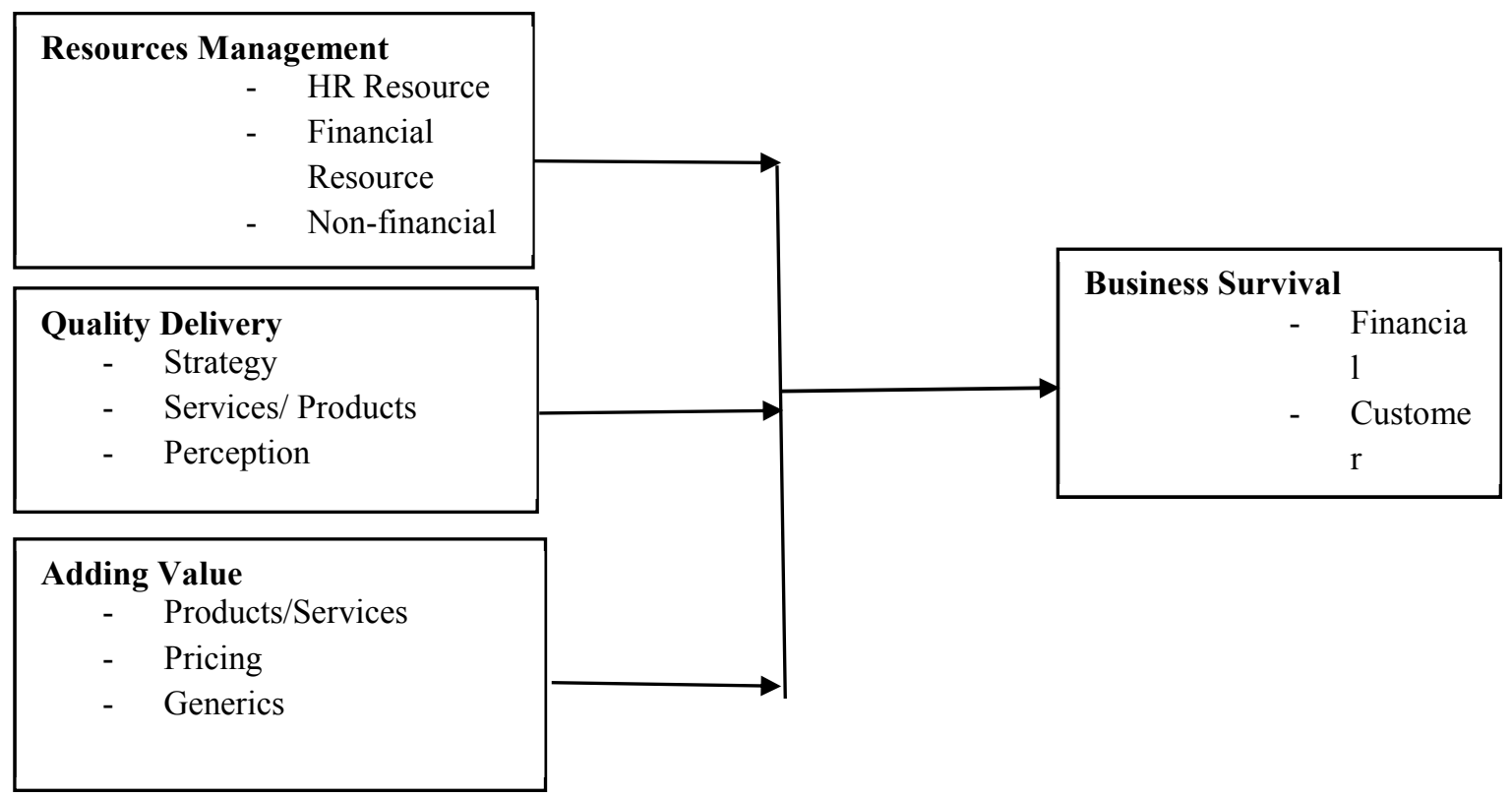

\section{Effectiveness and Efficiency}

\section{Business Survival}

\section{Figure 1: Effectiveness and Efficiency on Business Survival}

\subsection{Resources Management}

In today's global society, managers are constantly seeking to use available resources in the most effective and efficient an effort to survive in business. In order to weather through such difficult economic situations, it is imperative to work on efficiency on use of resources (Divleli, 2015). This call for management to evaluate all the available resources on their disposal and make the optimum utilisation on the best effective and efficient way possible.

\section{Human Resource Management}

The organisation management must successfully carry out the tasks that will ensure the institution reaches its purpose and targets. In other words, the manager is expected to reach and achieve certain aims by carrying out administrative functions, regardless of the institution's structure or current position level. The strategic management planning must be very well articulated for every one within the organisation to be able to understand and get acquitted to. They should be laid out in way that everyone can be able position himself/herself in their actualisation. This can be realised if the human resource is well conversant with the management vision and the methods to realise it.

Organisation leadership should therefore appreciate that the main resource among many resources is the human resource. Organisations which have embraced human resource and managed it efficiently and effectively have emerged successful in managing all other resources otherwise the opposite have seen organisations close doors on hit by a very small challenge. Leadership which knows when to switch leadership styles in an effort to improve their relationship with their employees are likely to have very effective and efficient labour force. On situations of difficult economic scenarios, the teamwork environment created will come up with innovations and ideas on how to counter the crisis and use it as an opportunity to leap from.

The top management needs to be effective in delivering the required tools and information and in time. The tactical management on their part are required to draw the short-term targets to deliver the organisational strategic planning. On sharing with their operatives, the need for consensus and agreement of possibilities increases the organisational teamwork and ownership of the targets. When the communication is effective and efficient on all levels of management, this increases trust and innovation on delivery of the planned targets.

\section{Financial Resource Management}

No organisation will ever survive without finances. Therefore, it is of utmost importance for managers to develop effective and efficient financial management tools. This will contribute on how an organisation survives an economic crisis. Financial management demands for a lot of accountability, transparency and openness at all levels of management. Normally the financial management is concerned with procurement, allocation and control of financial resources of a concern. Financial Management means planning, organizing, directing and controlling the financial activities like procurement and utilization of funds of the organisation. It means applying common management ideology to financial resources of the business organization. Effective and efficient financial 
management play a very important role in the success of every concern of the institution. The success of any organization lies on the availability, effective and efficient management of finance (Kadam, 2012).

The success of any business organization is expected. Profit is the tonic for the growth, sustainability and successful operation of the business organization. The organisation leadership plays a decisive role in the success of the organization in respective to effective and efficient utilisation of available scarcer resources. This involves raising funds, allocation of resources, dealing in capital market, planning of profit, etc. If the firm has efficient and effective leadership, the path of success of a firm will be clear. Hence the organisation management has to take clever and timely financial decisions depending on the changing time and competition and lead the business organization towards sustained success.

The major mistake management usually make is planning on anticipated financial resources. When economic crisis hits like the COVID-19 unexpectedly, the organisation operation is instantly crippled. Good effective and efficient financial management planning should be built on available funds. This makes it possible to quickly change plans in case unforeseen strikes and keep the operations of the organisation on course.

\section{Non-Financial Resource Management}

Non-financial resources are the organisation movable and fixed physical properties and assets. This includes land, buildings, vehicles, plants, machines, furniture, fixtures and all other assets. Organisation leadership should have effective and efficient utilisation of these non-financial resources for optimisation of survival of its operations. It is prudent for the organisation to ensure that all its properties and assets are in sound situation. This will enable the organisation to adopt any change in operations necessitate by an economic crisis like COVID-19 which strikes without warnings.

Many manufacturers who had their properties and assets in good situation, immediately adopted to the World Health protocols and changed their core business to COVID-19 requirements like protective garments, masks, sanitisers etc and earned from the crisis. Gaming in Kenya was hard hit by the government policy change and some differences on their stand on the business. When we were hit by the COVID-19 epidemic, gaming rebranded in our national and local social medias and took advantage of the idle citizens at their comfort of their homes. In fact, they might have made more money than ever before, Safaricom, being the biggest beneficiary. This was a benefit of effective and efficient use of available resources.

\subsection{Quality Delivery}

Efficiency covers quality otherwise it's the effort to maximise resources and time and reduce waste. When the strategic management are very clear on the institution requirements, all relevant specifications and deliverable are conveyed to the operatives in a language and manner they can understand easily and appreciate. When all levels of management are buying from the same script then everyone is proud on delivery of the required quality. This built on customer satisfaction and the institution corporate image.

\section{Strategy}

Delivering products or services of high quality is an important pursuit for providers that seek to create and provide value to their customers (Grönroos and Ravald, 2011). Through the provision of high levels of service quality, companies can achieve increased customer satisfaction, loyalty and therefore long-term profitability (Zeithaml and Bitner, 2000). In order to provide high levels of service quality and therefore create value for their customers, organisations need to plan the delivery of their products/services and to ensure the successful implementation of the actual plan (Parasuraman, Berry and Zeithaml 1985, 1988).

An organisation which upholds quality on delivery of its services and products are likely to survive economic turmoil as they have already built customers confidence and any change of pricing are not likely to affect the market share. However, every act affecting quality delivery should be very effective and efficient. This will include communication on any change either on supply or pricing or improvements thereof on the products/ services. Organisations which avoid taking advantage of the customers/ clients are likely to survive any economic crisis. Such organisations work on emotional intelligence of their customers and always endeavour to keep their feeling in mind. During difficult economic situations, the customers are likely to push them over.

\section{Service/ Product}

For an organisation to survive on effective and efficient quality delivery, then the organisation should have a very aggressive and creative research and development team to ensure that their products are always over and ahead of customer expectations and competitors. This increases customers faith and trust on their services/ products. For any organisation to keep their products/ services competitive, they have must have high level trade secrets to keep off those competitors who would wish to offer similar products/ services. This boils down to effective and efficiently handling of their employees to keep the company secret.

When an organisation has built their corporate image to quality services/ products any change of their services/ products is received positively and embraced as so by the customers. In events of economic crisis their new way of business is supported well by the market share who would push them over the crisis. 


\section{Perception}

An organisation which has a culture of satisfying its customers builds up a perception of caring organisation to its customers. This perception helps to push over to the market easily any new product. Customers are likely to stay and use services/ products of a particular organisation on the perception that they are better quality than the others. In Kenya, many Safaricom Ltd customers continue using their services on perception that they are stable and have better reception than others in the same market despite the Safaricom services having higher pricing.

During the COVID-19 epidemic, many major retail shops, Dry Cleaner and other business organisations introduced online ordering and deliveries to homes. This was easily embraced by customers built on the perception they had on their good quality products and customers were sure of getting the same services/ products. This ensured continuity of their businesses during the period building on their quality of services. Those who missed out like Tuskys Supermarket, Jade Ltd and others closed shops. This was possible through efficiency on effective quality delivery.

\subsection{Adding Value}

Value creation (effectiveness) and efficiency are both managerial strategies that have been around for a very long time. However, without a doubt, the dominant paradigm in the business world has been efficiency. Value creation has always taken a back seat to efficiency, especially since the time of the industrial revolution, leading to the widely held view that the two terms are incompatible. However, a renewed emphasis on value creation has highlighted some interesting managerial problems. Efficiency versus effectiveness, firm centric versus customer centric, objective versus subjective, functional versus emotional.

\section{Service/ Product}

Value-added is the additional features or economic value that a company adds to its products and services before offering them to customers. Organizations cannot exist without customers. But the way that organizations choose their most valuable customers, is also the same way that customers choose their preferred services/products. Customers look for the products which gives them the most value. This is a difficult revelation for managers, who seem to expect customer loyalty, but also seem to not be willing to do anything to add value for the most valuable customers, thus ensuring their loyalty. The shift to creating customer value has the potential to be a game changer in the marketplace. Unfortunately, managerial practices have not yet caught up with this shift, and in a lot of cases, managers are still managing according to the outdated firm-centric manufacturing paradigm, thus inadvertently destroying productivity, instead of creating it. Thus, most service failures or value destruction are not really failures. They have been designed into the system by the misguided choices that managers have made (Schlesinger \& Heskett, 1991). The policies that guide employees have been determined by managers. Instead of helping the employee to help the customer, these policies force employees to overlook customer problems and focus solely on the policy. When the policy is more important than the customer problem or need, everybody loses.

Safaricom Ltd and other organisations took advantage of the COVID-19 epidemic crisis and introduced products to support online learning and other products geared on making idle people busy at home on very low rates. This ensured keeping on check of their customers without losing them while still making money from them. There must have been quick and abrupt change of policies and strategic planning and reap from the crisis at these companies. This was as a result of company efficiency and effective value creation for customers. This can only happen to very vibrant organisation with very creative human resource.

\section{Pricing}

Adding value to a product or service helps companies attract more customers, which can boost revenue and profits. Customers always are likely to come back for a service/product if it adds value. Organisations leadership which endeavours to have services/products which add value to customers are always effective and efficient in their strategic planning. Even when situations are difficulty, they always have something to put a smile to their customers. These are the organisations which are ready to trade profit for customer satisfaction. They lower pricing on basic needs for customer required products. When customers notice how much they value their lives, they are not likely to feel the relatively higher pricing on non-basic needs products.

Value-added is effectively the difference between a product's price to consumers and the cost of producing it. Noticing the challenge parents had due to COVID-19 epidemic, many retail outlets put huge discounts to back to school products to help parents afford them. Customers to such outlets got this as value added products which put a smile on their faces.

\section{Generics}

Value can be added in several different ways, such as adding a brand name to a generic product or assembling a product in an innovative way. To save the organisation on break even production versus sale costs, organisations with efficient and effective strategies on adding value to customers, come up with alternative services/ products to their usual higher priced to serve the same purpose. This helps the organisation to survive the economic crisis while retaining its customers happy. 


\subsection{Business Survival}

The survival of any organisation depends on its leadership. Empirical evidence has shown that survival of any organisation depends on how efficiently and effectively it; manages its finances, customer retention and corporate image.

\section{Financial Survival}

Organisational financial performance is denoted by profit, shares, dividends etc and one of the most visible threats from the current financial crisis for economic performance, at least as portrayed by the media, is the closure of firms and the resulting employment losses in the economy. Drop in demand and lack of access to external finance may seriously impede firms with the result that some have to shut down. Profit is the tonic for the growth, sustainability and successful operation of any business organization.

For survival of any organisation its prudent to operate within its financial means. This will ensure it is able to meet its financial obligations effectively and effectively. Delayed payments to suppliers, employees and other requirements due to delayed finances drops the organisations performance and makes it very difficult to survive any abrupt economic crisis like COVID-19 epidemic.

\section{Customer Retention}

No organisation will exist without customers and their retention is key. The fundamental purpose of customer retention efforts is to ensure maintaining relationships with value-adding customers by reducing their defection rate. Creating customer loyalty is essential for the survival of the company in highly competitive markets. Retention marketing strategies provide many benefits to the company because loyal customers increase their spending at an increasing rate, purchase at a full margin rather than at discount prices, and create operating efficiencies (Reichheld \& Sasser, 1990).

Companies must aim for high satisfaction; because high satisfaction creates an emotional bond with the firm and in turn, this will lead to customer retention. Providing superior value, which will delight customers, is the most reliable way to ensure sustainable customer satisfaction and customer loyalty. On the other hand, delivering poor product and/or service is the main source of dissatisfaction (Nasir, 2017).

\section{Corporate Image}

Corporate image, or reputation, describes the manner in which a company, its activities, and its products or services are perceived by outsiders. In a competitive business climate, many businesses actively work to create and communicate a positive image to their customers, shareholders, the financial community, and the general public. A company that mismanages or ignores its image is likely to encounter a variety of problems.

Some of the warning signs that a business might have an image problem include high employee turnover, the disappearance of major customers, a drop in stock value, and poor relationships with vendors or government officials. If an image problem is left unaddressed, a company might find many of its costs of doing business rising dramatically, including the costs of product development, sales support, employee wages, and shareholder dividends. In addition, since the majority of consumers base their purchase decisions at least partly on trust, current and future sales levels are likely to suffer as well. A company with poorly managed corporate image suffers badly when an economic calamity like COVID-19 strikes and may not be possible to survive.

\section{Conclusion}

The success or failure of any organisation depends on its leadership despite the prevailing environment. Empirical evidence has shown that survival of any organisation depends on how efficiently and effectively it manages its resources, maintains its quality delivery and adds value to its consumers. This could be summarised as follows; Effective and efficient management of human resource of any organisation enables the organisation an advantage in managing all other resources; financial or non-financial. Human resource is very unique resource as all other resources are utilised and managed by the employees. Employees who are satisfied are always proud of the company performance and will always monitor its financial, customer retention and corporate image and do all what it takes to maintain them. This very vibrant work force would develop ability to creativity and proactiveness that enables the organisation to quickly adopt to any economic crises and successfully sail through.

When the board of directors comes up with very effective and efficient quality delivery strategies, it becomes very easy and practical for the tactical and the operatives' levels of management to implement. A conducive working environment across all levels of management would enable the sustainability of the quality delivery. This consistency of quality delivery would be appreciated customers and develop to trust on the organisation's services/ products and a positive perception. This then would contain the company financial, customer retention and corporate and make it easier push through any abrupt change of business environment like COVID-19 epidemic.

Adding value in provision of exemplary services/ products, minding customers on pricing and providing alternative services/products to enable your customers afford helps greatly in business survival. Efficient and effective creation of value to customers keeps the institution health financially, retains customers and keeps the corporation image high. Such endeavours cushion the organisation during any unexpected economic crash like the COVID-19 epidemic and ensure the institution survives through with their customers. 


\section{Reference}

Anderson R., Swaminathan S. \& Mehta R., 2018. Prospering in Tough Economic Times through Loyal Customers. International Journal of Management and Economics 41(1), 76-91; http://www.sgh.waw.pl/ijme/.

Covey, S. R. (2011). 8th Habit from Effectiveness to Greatness. Simon \& Schuster UK Ltd, 1st Floor, 222 Gray's Inn Road London WC1X 8HB, 74-98.

Divleli, M., Ergun, E. (2015). Manager Effectiveness and Efficiency: The Effect of Skills On Different Level Management. International Journal of Management and Human Resources, 3(1), 1-100. https://www.researchgate.net/publication/334965265.

Grönroos, C., \& Ravald, A. (2011). "Service as business logic: implications for value creation and marketing." Journal of Service Management, 22(1), 5-22.

Harper D. (2009). Business Survival Strategies for tough economic times. 2009 Harper Capital Advisors.

Kadam, R. N. (2012). Financial Management for The Organizational Success: Challenge Before Finance Managers. International Journal of Advanced Research in Management and Social Sciences. 1(1), 128-134.

Lashgari, M. (2014). Corporate Governance: Theory and Practice. The Journal of American Academy of Business, Cambridge University of Hartford, West Hartford, CT. 9(1), 1-51.

Mensah, S. (2012). Corporate governance in Ghana: issues and challenges. Paper presented at African Capital Markets Conference, December 2012.

Nasir, S., (2017). Customer Relationship Management Strategies in the Digital Era. Business Science Reference (an imprint of IGI Global), 701 E. Chocolate Avenue. (ISSN: 2327-5502; eISSN: 2327-5529), 244-247.

Parasuraman, A., Zeithaml, V. A., and Berry, L. L., (1985) "A conceptual model of services quality and its implications for future research.” Journal of Marketing. 49(3), 41-50.

Reichheld, F. P., \& Sasser, W. E. (1990). Zero defections: Quality comes to services. Harvard Business Review, 68(9), 105-267. 111. PMID:10107082.

Schlesinger, L. A., \& Heskett, J. (1991, September-October). The service driven service company. Harvard Business Review, 69(5), 71-81.

Weber, U., Slovic, P, (2002) Perception of Risk Posed by Extreme Events. Conference "Risk Management strategies in an Uncertain World," Palisades, New York, April 12-13, 2002.: https://www.researchgate.net/publication/209805350.

Zeithaml, V.A., and Bitner, M.J. (2000) Services Marketing - Integrating Customer Focus across the Firm. 2nd Edition. The McGraw Companies, Inc., New York. 